\title{
Enzyme Inhibition
}

National Cancer Institute

\section{Source}

National Cancer Institute. Enzyme Inhibition. NCI Thesaurus. Code C40577.

Enzyme Inhibition involves interference with, or restraint of, the function of a biological molecule that possesses catalytic activity. 